\title{
DISTRIBUTION AND STATUS OF THE YELLOW-FACED POCKET GOPHER IN KANSAS
}

\author{
Justin D. Hoffman ${ }^{1,2}$ and Jerry R. Choate ${ }^{1}$
}

\begin{abstract}
Previous research suggests that the yellow-faced pocket gopher (Cratogeomys castanops) occupies a restricted range in western Kansas that is surrounded by the range of the plains pocket gopher (Geomys bursarius), which is regarded as a superior competitor. To determine whether the plains pocket gopher has encroached on the range of the yellow-faced pocket gopher in the past 35 years and to better understand the geographic relationships of these species, we trapped pocket gophers in western Kansas and collected soil texture and land cover data. We used ArcView 3.2 to map the distributions of these species in the study area, as well as the kinds of soil and land cover found in their potential home ranges. Although the distributions of the 2 species overlap, they are strictly parapatric. The apparent cause of this parapatric relationship is differential tolerance of soil textures. The distribution of the yellow-faced pocket gopher in Kansas is limited to just 7 counties divided into 2 populations, both surrounded by the distribution of the plains pocket gopher. We found no evidence that the range of the plains pocket gopher has expanded at the expense of the yellow-faced pocket gopher in the past 35 years. Thus, although the yellow-faced pocket gopher remains a "species of greatest conservation need" in Kansas because of agricultural threats, it evidently is not imperiled at this time.
\end{abstract}

Key words: Cratogeomys castanops, Geomys bursarius, habitat preferences, Kansas, distribution, conservation status.

Although Cockrum (1952) and Hall (1955) listed the yellow-faced pocket gopher (Cratogeomys castanops) as a mammal that likely occurred in Kansas, the species was not known to occur in the state until 1968, when specimens were collected in Hamilton, Finney, and Hodgeman counties (Birney et al. 1971). Prior to that time, the species had been reported from a locality in Baca County, Colorado, 2 miles west of the Kansas state line (Cary 1911), and 2 fossil specimens had been found in a Pleistocene deposit in Meade County, Kansas (Rinker 1941, Hibbard, 1944). Additional fieldwork in west central Kansas in 1968 and 1969 revealed the presence of populations of the yellow-faced pocket gopher in Ford, Gray, and Lane counties, bringing the number of counties in Kansas wherein the species was known to occur to 6 (Birney et al. 1971).

As mapped by Birney et al. (1971), the distribution of the yellow-faced pocket gopher in Kansas appeared to be restricted to deep upland soils north of the Arkansas River, where it was surrounded by the distribution of the plains pocket gopher (Geomys bursarius). Based on the results of Miller (1964), who proposed that a dominant species of pocket gopher always competitively excludes the other, Birney et al.
(1971) suggested that the plains pocket gopher is dominant to the yellow-faced pocket gopher in friable soils, thereby restricting the distribution of the latter to areas of shortgrass rangeland with hardpan soils.

Subsequent research on pocket gophers in southeastern Colorado (Moulton et al. 1979) revealed a narrow zone of sympatry (or parapatry) between the yellow-faced pocket gopher and Botta's pocket gopher (Thomomys bottae), with adjacent populations of the plains pocket gopher. The results of this study suggested that the plains pocket gopher is better adapted for disturbed habitats than the other pocket gopher species and may displace them when shortgrass rangeland is cultivated for agricultural purposes (Moulton et al. 1983). A comprehensive review of the geographic relationships of pocket gophers in southeastern Colorado (Lovell et al. 2004) proposed that, before agricultural development and the Dust Bowl, the plains pocket gopher was restricted to sandy river bottomland on the High Plains. Intensive cultivation and construction of elevated, sandy roads established corridors of suitable habitat for the plains pocket gopher and enabled that species to disperse into regions previously occupied by the yellow-faced and Botta's pocket gophers.

\footnotetext{
${ }^{1}$ Department of Biological Sciences and Sternberg Museum of Natural History, Fort Hays State University, Hays, KS 67601.

${ }^{2}$ Present address: Department of Biological and Environmental Science, McNeese State University, Lake Charles, LA 70609. E-mail: jhoffman@mcneese.edu
} 
These studies suggested that the yellowfaced pocket gopher in Kansas might be threatened if agricultural development or road maintenance enabled encroachment into its range by the plains pocket gopher. For this reason, the yellow-faced pocket gopher was listed by the Kansas Department of Wildlife and Parks as a "species of greatest conservation need" in the state's Comprehensive Wildlife Conservation Plan (available from: http://www.kdwp.state.ks .us/other_services/wildlife_conservation_plan/ kansas_cwcp). The objectives of our study were to (1) ascertain the current distribution of the yellow-faced pocket gopher in Kansas, (2) determine whether its distribution in Kansas has diminished since it was last mapped in 1971, (3) document whether the yellow-faced and plains pocket gophers are sympatric in Kansas, and (4) investigate the factors that influence the distributions of these species. We tested 2 null hypotheses: (1) that the 2 species do not inhabit soils with different textures, and (2) that the 2 species are not separated by the presence or absence of a disturbance in an area.

\section{METHODS}

The study area consisted of 8 counties in western Kansas: Finney, Ford, Gray, Hamilton, Hodgeman, Kearny, Lane, and Ness. Most of the land in the study area was used for farming or ranching, and the principal crops were wheat, alfalfa, and corn. Large tracts of native prairie occurred in the northeastern part of the study area, especially in eastern Finney, western Hodgeman, and Ness counties (Küchler 1974). In the remainder of the study area, undisturbed tracts of prairie occurred in small, isolated patches.

We compiled a list of all known localities in the study area where specimens of the 2 species had been trapped. The specimens are housed in the collections of the Sternberg Museum of Natural History at Fort Hays State University (MHP) and the Kansas University Natural History Museum (KU). Additionally, we used Macabee traps to collect pocket gophers throughout the region in spring and summer of 2002 . We examined a total of 413 specimens from 156 capture localities (yellow-faced pocket gopher, $n=52$; plains pocket gopher, $n=$ $104)$ and an additional 40 localities from outside the study area (Appendixes 1,2). Capture localities were plotted using ArcView 3.2.
We took a soil sample and GPS coordinates from the mound where we trapped each gopher. Soil samples were placed in paper bags to dry, and the topography, predominant vegetation, and land use at each capture site were recorded. All specimens were prepared as vouchers and deposited in MHP.

We used the hydrometer method (Kilmer and Alexander 1949) to determine the amount of sand, silt, and clay in soil samples. Soil texture data were analyzed using SPSS (2002). Potential relationships between the 2 pocket gopher species and soil texture were analyzed using a principal components analysis (PCA) with a Kaiser stopping rule of one eigenvalue. A 1-sample Kolmogorov-Smirnov test indicated that the percentages of sand, silt, and clay were not normally distributed among samples. Therefore, differences between soils in which the 2 species were captured were assessed with a Mann-Whitney $U$ test (Zar 1999). Additionally, each capture site was characterized as disturbed or undisturbed based on the type of vegetation and land use found adjacent to the capture site. Data on differences in land use between the 2 species were analyzed using a chi-square test of independence.

County-level habitat data were obtained from the Data Access and Support Center (DASC) for Kansas (http://www.kansasgis.org/). Using ArcView 3.2, digitized Soil Survey Geographic (SSURGO) and Gap Analysis Program (GAP) land cover databases of the study area were downloaded and converted to grid format with a cell size of $25(25 \times 25 \mathrm{~m})$. For each captured individual, a circle with a $155.5-\mathrm{m}$ radius was mapped around the capture location. The 155.5-m radius represents a potential home range for a pocket gopher (Downhower and Hall 1966). The cell size of 25 was chosen because it was fine enough to characterize variation in soil texture and land use within the potential home range. Each $25 \times 25 \mathrm{~m}$ cell represented 1 pixel of either soil texture or land cover type. The number of pixels of each soil texture and land cover type that fell within the potential home range was determined for each pocket gopher. Then pixel values for both soil and land cover were summed to show the respective amounts of soil texture and land cover types used by each species within the study area. A chi-square test of independence was used to test for differences between observed and expected counts of soil 


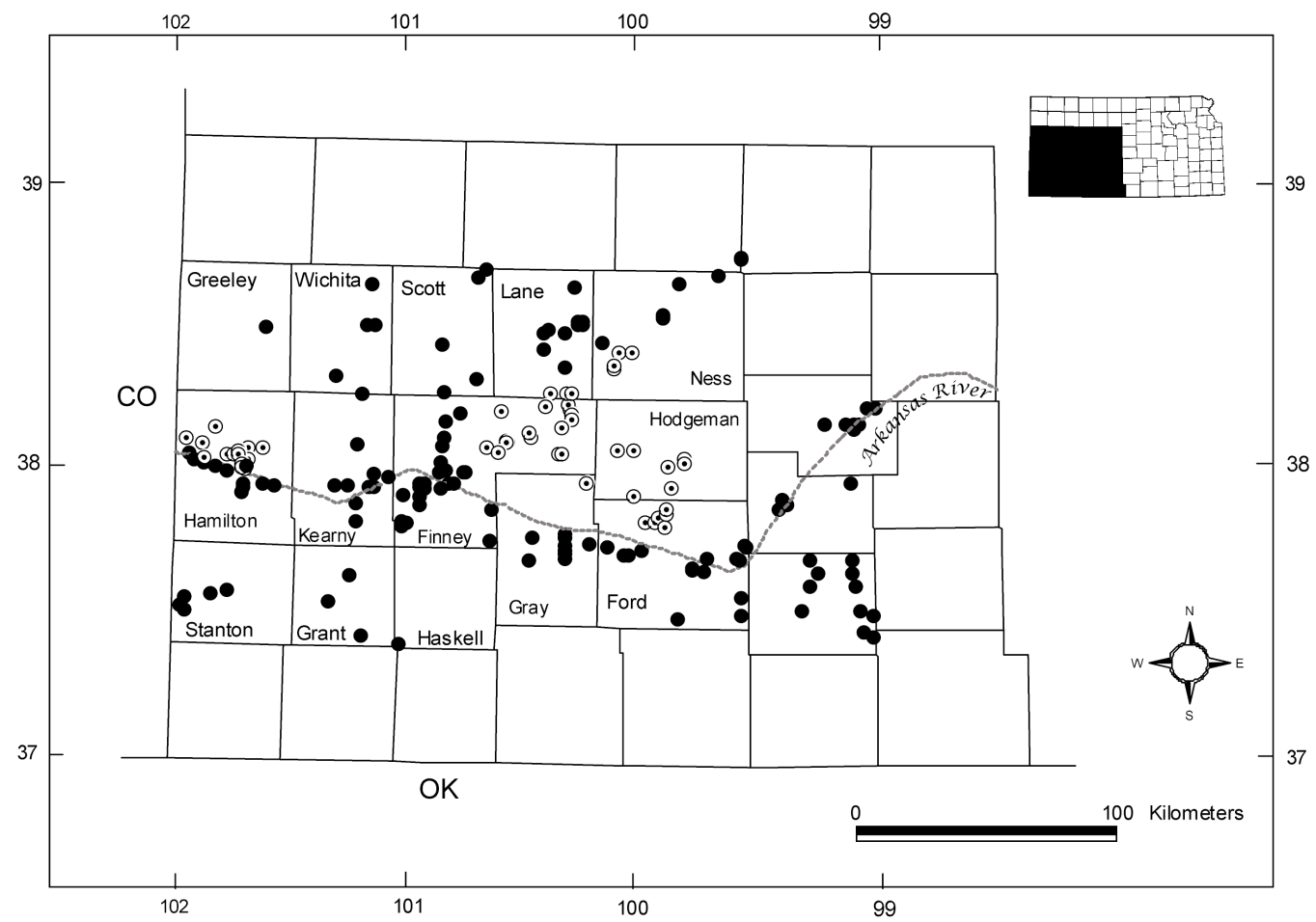

Fig. 1. Current distribution of pocket gophers in the study area. Solid circles represent Geomys bursarius, and open circles represent Cratogeomys castanops.

texture and land cover pixels both within and between species with respect to soil texture (SSURGO) and land cover type (GAP). Land cover types that had expected values lower than 118 were excluded from the analysis between species, whereas all soil textures identified were used in the analysis. Observed and expected values for a chi-square test of independence were calculated to test for differences in species' habitat preferences for land cover and soil texture. Preliminary results indicated that yellowfaced pocket gophers did not occur in areas with clay, sand, or loamy sand soils or in sand prairie habitat; therefore, the preferences of the plains pocket gopher were used to calculate the expected values, because the chisquare test of independence requires that no results equal zero. Expected values were calculated by dividing the pixel count of each soil texture that fell within the potential home range for the plains pocket gopher by the total pixel count area for that species. This value then was multiplied by the total pixel count for the yellow-faced pocket gopher, which gave an expected value. The same procedure was used for land cover. Pixel counts for each soil texture and land cover type for the yellow-faced pocket gopher were used as the observed values in their respective analyses. These procedures were previously used (Hoffman et al. 2007) to explain the absence of pocket gophers from large tracts of land in western Kansas. In our study, these methods were used to compare habitat tolerance in the 2 species of pocket gopher.

\section{RESUlTS}

All localities of record for the yellow-faced pocket gopher in Kansas were located north of the Arkansas River (Fig. 1). Yellow-faced pocket gophers occurred in 2 disjunct patches that were separated by populations of the plains pocket gopher. The western population of the yellow-faced pocket gopher may be contiguous with the overall distribution of the species in Colorado and southwestward into Mexico (Lovell et al. 2004). In this population, yellowfaced pocket gophers occurred primarily in disturbed roadside ditches adjacent to crop and 
TABLE 1. Numbers of pixels of each soil texture type within the potential home ranges of Geomys bursarius and Cratogeomys castanops in Kansas. The percentage of total pixels in each soil texture type is given for G. bursarius. The observed and expected numbers of pixels, with their respective percentages, are given for each soil texture type for $C$. castanops.

\begin{tabular}{|c|c|c|c|c|c|c|}
\hline \multirow[b]{2}{*}{ Soil texture } & \multicolumn{2}{|c|}{ Geomys bursarius } & \multicolumn{4}{|c|}{ Cratogeomys castanops } \\
\hline & $\begin{array}{c}\text { Pixels } \\
\text { observed }\end{array}$ & $\begin{array}{l}\text { Percent of } \\
\text { total pixels }\end{array}$ & $\begin{array}{c}\text { Pixels } \\
\text { observed }\end{array}$ & $\begin{array}{l}\text { Percent of } \\
\text { observed } \\
\text { pixels }\end{array}$ & $\begin{array}{c}\text { Pixels } \\
\text { expected }\end{array}$ & $\begin{array}{l}\text { Percent of } \\
\text { expected } \\
\text { pixels }\end{array}$ \\
\hline Clay loam & 664 & 0.10 & 1197 & 0.19 & 605.5 & 0.10 \\
\hline Loam & 530 & 0.08 & 429 & 0.07 & 483.3 & 0.08 \\
\hline Silt loam & 2282 & 0.34 & 4017 & 0.65 & 2081.1 & 0.34 \\
\hline Silty clay loam & 17 & 0.00 & 416 & 0.07 & 15.5 & 0.00 \\
\hline Clay & 26 & 0.00 & 0 & 0.00 & 23.7 & 0.00 \\
\hline Sandy loam & 918 & 0.14 & 94 & 0.02 & 837.2 & 0.14 \\
\hline Sand & 993 & 0.15 & 0 & 0.00 & 905.6 & 0.15 \\
\hline Loamy sand & 1317 & 0.20 & 0 & 0.00 & 1201.1 & 0.20 \\
\hline
\end{tabular}

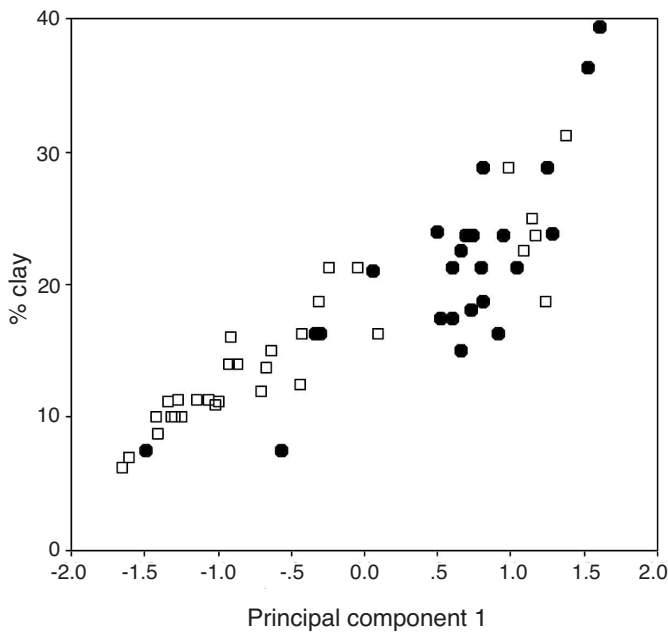

Fig. 2. Scatter plot from principal components analysis. Open squares represent Geomys bursarius, and closed circles represent Cratogeomys castanops.

Conservation Reserve Program (CRP) fields. Soils ranged from coarsely textured sandy soils to silt loams. We surveyed the locality where Birney et al. (1971) collected both species sympatrically in a roadside ditch, but we caught only the yellow-faced pocket gopher. The eastern population inhabited a mixture of undisturbed prairie and areas dominated by disturbance vegetation. Soils found within this part of the study area were finely textured.

The 1st principal component explained $85.6 \%$ of the variation in soil texture (Fig. 2). Other principal components were not extracted in the analysis because their eigenvalues were $<1$. Because only one principal component was extracted, the variable (clay) with the least amount of variation explained $(76 \%)$ was plotted on the $y$-axis to aid in visualization. All 3 variables (percent sand, percent silt, and percent clay) loaded heavily on the 1st principle component. Percent silt and percent clay were positively loaded, whereas percent sand was negatively loaded. When the 2 species of pocket gopher were compared, soil texture differed: for percent sand, the plains pocket gopher had a higher mean rank (Mann-Whitney $U=$ 192.5, $\mathrm{df}=1, P<0.001$ ); for percent silt, the yellow-faced pocket gopher had a higher mean rank (Mann-Whitney $U=154.0, \mathrm{df}=$ $1, P<0.0001$ ); for percent clay, the yellowfaced pocket gopher had a higher mean rank (Mann-Whitney $U=215.5$, df $=1, P<$ $0.003)$. Potential-home-range data analyses indicated differences in soil textures inhabited by the 2 species: the yellow-faced pocket gopher occurred in clay loam and silt loam more than expected $\left(\chi^{2}=22777.3\right.$, df $=8, P$ $<0.001$ ), whereas the plains pocket gopher occurred in loamy sand, sandy loam, sand, and clay loam more than expected $\left(\chi^{2}=8366.8\right.$, df $=8, P<0.001)$. A significant difference also was detected between species $\left(\chi^{2}=15520.7\right.$, df $=8, P<0.001$ ), with the yellow-faced pocket gopher occurring in clay loam, silt loam, and silty clay loam soil textures more than expected and in sandy loam, sand, and loamy sand soil textures less than expected (Table 1).

Presence of the plains pocket gopher was influenced by land cover $\left(\chi^{2}=4.0, \mathrm{df}=1, P\right.$ $<0.05)$ in that this species occurred in disturbed habitats more frequently than in undisturbed habitats. Presence of the yellow-faced pocket gopher, on the other hand, was not 
TABLE 2. Numbers of pixels of each land cover type within the potential home ranges of Geomys bursarius and Cratogeomys castanops in Kansas. The percentage of total pixels in each land cover type is given for G. bursarius. The observed and expected numbers of pixels for each land cover type along with their respective percentages are given for C. castanops.

\begin{tabular}{|c|c|c|c|c|c|c|}
\hline \multirow[b]{2}{*}{ Land cover type } & \multicolumn{2}{|c|}{ Geomys bursarius } & \multicolumn{4}{|c|}{ Cratogeomys castanops } \\
\hline & $\begin{array}{c}\text { Pixels } \\
\text { observed }\end{array}$ & $\begin{array}{l}\text { Percent of } \\
\text { total pixels }\end{array}$ & $\begin{array}{c}\text { Pixels } \\
\text { observed }\end{array}$ & $\begin{array}{c}\text { Percent of } \\
\text { observed } \\
\text { pixels }\end{array}$ & $\begin{array}{c}\text { Pixels } \\
\text { expected }\end{array}$ & $\begin{array}{l}\text { Percent of } \\
\text { expected } \\
\text { pixels }\end{array}$ \\
\hline Cultivated land & 3120 & 0.44 & 1474 & 0.24 & 2946.4 & 0.47 \\
\hline Mixed prairie & 821 & 0.12 & 301 & 0.05 & 775.3 & 0.12 \\
\hline Sandsage shrubland & 1080 & 0.15 & 503 & 0.08 & 1019.9 & 0.16 \\
\hline Sand prairie & 126 & 0.02 & 0 & 0.00 & 119.0 & 0.02 \\
\hline Shortgrass prairie & 459 & 0.06 & 1401 & 0.22 & 405.6 & 0.06 \\
\hline Western wheatgrass prairie & 132 & 0.02 & 915 & 0.15 & 124.7 & 0.02 \\
\hline CRP (Conservation Reserve Program) & 524 & 0.07 & 887 & 0.14 & 494.8 & 0.08 \\
\hline Urban areas & 199 & 0.03 & 232 & 0.04 & 187.9 & 0.03 \\
\hline Cottonwood floodplain woodland & 616 & 0.09 & 540 & 0.09 & 581.7 & 0.09 \\
\hline
\end{tabular}

influenced by land cover $\left(\chi^{2}=0.29, \mathrm{df}=1, P\right.$ $>0.05)$. Analyses of potential-home-range data indicated differences between the species in tolerance of land cover: the yellow-faced pocket gopher occurred in cottonwood floodplain woodland, CRP, sandsage scrubland, shortgrass prairie, and western wheatgrass more often than expected $\left(\chi^{2}=30031.7, \mathrm{df}=28, P\right.$ $<0.001$ ), whereas the plains pocket gopher was found in cottonwood floodplain woodland, mixed prairie, sand prairie, sandsage scrubland, and urban areas more often than expected $\left(\chi^{2}\right.$ $=7765.0, \mathrm{df}=28, P<0.001)$. Nine land cover types were used for tests between species. A significant difference was detected $\left(\chi^{2}=9484.5, \mathrm{df}=8, P<0.001\right)$, with the yellow-faced pocket gopher occupying shortgrass prairie, western wheatgrass prairie, and CRP fields more than expected and cultivated land, mixed prairie, sand prairie, and sandsage prairie less than expected (Table 2).

\section{Discussion}

Although the geographic ranges of the plains and yellow-faced pocket gophers overlap in Kansas, investigation at the local scale demonstrated segregation of their distributions. This segregation was formerly described as "contiguous allopatry" (Miller 1964), but the term now used for this pattern is "parapatry" (Vaughan 1967). The distributions of these 2 species approached each other, but no zone of contact was found. In fact, a buffer zone that was not occupied by either species existed between them (Fig. 1). This phenomenon has been noted for other species of pocket gophers. Kennerly (1959) found a 17.7-km gap between populations of the Texas pocket gopher (Geomys personatus) and the plains pocket gopher. Likewise, Best (1973) documented a 29-km gap between populations of Botta's pocket gopher (Thomomys bottae) and the yellow-faced pocket gopher. The results of our geographic analysis indicate that 2 populations of the yellow-faced pocket gopher occur in Kansas (Fig 1). This species once inhabited a larger area in the state, as shown by skeletal remains collected from a Recent terrace in Meade County, well to the south of both the study area and the Arkansas River (Rinker 1941, Hibbard 1944). The only pocket gopher presently occurring in Meade County is the plains pocket gopher. Populations of the yellow-faced pocket gopher that presently occur in Kansas are isolated from each other by the distribution of the plains pocket gopher. We suspect that the 2 populations of the yellow-faced pocket gopher were contiguous before much of western Kansas was cultivated for farming. Cultivation favors the plains pocket gopher and undoubtedly enabled this species to encroach upon the range of the yellow-faced pocket gopher (Birney et al. 1971).

The hydrometer soil test results and PCA analysis confirmed previous studies (Miller 1964, Best 1973, Moulton et al. 1983, Lovell et al. 2004) indicating that the 2 species inhabit soils with different textures, the plains pocket gopher occurring primarily in sandy soils and the yellow-faced pocket gopher associated with soils high in clay and silt. Therefore, we reject 
our 1st null hypothesis that the plains and yellow-faced pocket gophers do not inhabit soils of different texture. However, the 2 species are not mutually exclusive with respect to soil texture. Six out of 33 plains pocket gophers trapped in north central Ness and southeastern Trego counties were living in hardpan rangeland with soils high in clay and silt content. These results were contrary to those found in the remainder of the study area. One explanation is that, as population density rises within preferred habitats, some individuals expand into adjacent, less-preferred habitats (Rosenzweig 1991). Thus, the population density of plains pocket gophers in nearby sandy soils might have reached its carrying capacity, forcing excess individuals into areas with suboptimal soil textures.

In Colorado, Moulton et al. (1983) and Lovell et al. (2004) found yellow-faced pocket gophers primarily in undisturbed rangelands, whereas plains pocket gophers occurred primarily in disturbed habitats. These researchers concluded that land-use practices have had an impact on the distributions of these species. Our results indicated that the plains pocket gopher does, in fact, occur in disturbed habitats more than expected but that the yellowfaced pocket gopher does not show a preference for either disturbed or undisturbed habitats. Other studies also have noted that the yellowfaced pocket gopher readily inhabits disturbed areas (Russell and Baker 1955, Russell 1968, Best 1973). Because there is overlap in the habitat types the species occupy, we accept our 2 nd null hypothesis that the 2 species are not separated by the presence or absence of disturbance in an area.

Analysis of soil texture and land cover at the potential home-range scale substantiated our assessment of the relationship between pocket gopher occurrence and habitat type. The results of soil texture analysis within potential home ranges agreed with the soil data taken from collection sites, namely that plains pocket gophers occupy sandy-textured soils and yellow-faced pocket gophers occur in hardpan soils containing silt and clay. The land cover analysis within potential home ranges showed that plains pocket gophers occur in cultivated areas and undisturbed sandsage, sand, and mixed prairies. Two of these land cover types (sandsage and sand prairie) occur on sandy substrates. Cultivated habitats typi- cally are characterized by loamy soils, which normally are not preferred by the plains pocket gopher; however, because of cultivation, these areas can be converted to favorable habitat (Moulton et al. 1983, Lovell et al. 2004). For example, in Finney County we collected plains pocket gophers in an alfalfa field containing silt loam-textured soil. Yellow-faced pocket gophers occur in a wide range of native habitat types and CRP fields, the latter of which, in the study area, were found mostly on hardpan substrates. This suggests that these fields were unsuitable habitat for the plains pocket gopher until cultivation made them friable. In Lane County, we caught plains pocket gophers in CRP fields containing both loam- and silt loam-textured soils. In conjunction with soil texture, the land use present in a certain area can tell us more about the distribution of pocket gophers. We found that sandy habitats are occupied almost exclusively by plains pocket gophers; however, nonsandy habitats are not occupied exclusively by yellow-faced pocket gophers. As noted by Lovell et al. (2004), the presence of cultivation or disturbance in nonsandy habitats allows plains pocket gophers to invade otherwise unfavorable situations.

Segregation of pocket gopher species has been the subject of much debate, with various hypotheses being examined. For instance, Miller (1964) suggested that separation of pocket gopher species was due to competitive exclusion based on a linear, hierarchical relationship among the different species. Specifically, he stated that the plains pocket gopher was a superior competitor to the yellow-faced pocket gopher, primarily because the plains pocket gopher was found almost exclusively in sandy soil, which he considered the preferred habitat of all pocket gopher species. In contrast, Best (1973) and Moulton et al. (1983) suggested that segregation was due to different tolerances to soil texture among species of pocket gophers and disruption of habitats, not interspecific competition. Lovell et al. (2004) stated that the yellow-faced pocket gopher was as well suited for digging in compacted soils as it was in sandy or otherwise friable soils. This conclusion is supported by anatomical work conducted by Lessa and Thaeler (1989), who found that gophers of the genus Geomys (including the plains pocket gopher) are adapted for claw-digging, gophers of the genus Thomomys are adapted for tooth-digging, and 
gophers of the genus Cratogeomys (including the yellow-faced pocket gopher) possess modifications intermediate between Geomys and Thomomys. They concluded that claw-diggers occur primarily in sandy substrates, whereas modifications for tooth-digging allow other pocket gophers to live in a broader range of soil textures. Therefore, the yellow-faced pocket gopher has a broad range of tolerance for soil texture and does not prefer sandy soils.

In conclusion, our research showed that the current distribution of the yellow-faced pocket gopher in Kansas includes parts of 7 western counties. This distribution is divided into 2 populations by the distribution of the plains pocket gopher. Encroachment of the plains pocket gopher on populations of the yellowfaced pocket gopher was not observed since they were last studied in 1971. We documented no instances of current sympatry of the 2 species in Kansas, and we therefore conclude that their distributions are parapatric. Soil texture is a major factor influencing the distribution of these 2 species, and the amount of disturbance in an area is not a reliable indicator of pocket gopher occurrence. Disturbances (such as cultivation) can convert otherwise unsuitable habitats to favorable habitats, as documented by Moulton et al. (1983) in Colorado, unless that disturbance is too severe (Hoffman et al. 2007). Our results agree with other studies (Lessa and Thaeler 1989, Lovell et al. 2004), which suggest that the yellow-faced pocket gopher is well suited for inhabiting a wide range of soil types. This suggests that the segregation of pocket gophers in Kansas is due to differences in habitat tolerance between the 2 species. Competition between the species may occur when natural habitats are disrupted. Finally, we found no evidence that the yellowfaced pocket gopher is currently imperiled in Kansas by its relationship with the plains pocket gopher.

\section{ACKNOWLEDGMENTS}

We thank R.B. Channell, W.J. Stark, E.J. Finck, and R.J. Zakrewski for their comments, suggestions, and help in designing this project. We also thank J. Gleichsner for providing advice and guidance with the analysis of the soil samples and the Department of Agriculture, Fort Hays State University, Hays, Kansas, for allowing us to use equipment needed for the soils analysis. Our work was funded in part by the Department of Biological Sciences, Fort Hays State University.

\section{Literature Cited}

BEST, T.L. 1973. Ecological separation of three genera of pocket gophers (Geomyidae). Ecology 54:1311-1319.

Birney, E.C., J.K. Jones, JR., And D.M. Mortimer. 1971. The yellow faced pocket gopher, Pappogeomys castanops, in Kansas. Transactions of the Kansas Academy of Science 73:368-375.

Cary, M. 1911. A biological survey of Colorado. North American Fauna 33:1-256.

Cockrum, E.L. 1952. Mammals of Kansas. University of Kansas Publications, Museum of Natural History 7: $1-303$

Downhower, J.F., and E.R. Hall. 1966. The pocket gopher in Kansas. Miscellaneous Publications of the Museum of Natural History, University of Kansas 44:1-32.

HALL, E.R. 1955. Handbook of mammals of Kansas. University of Kansas Museum of Natural History Miscellaneous Publications 7:1-303.

HibbaRD, C.W. 1944. A checklist of Kansas mammals, 1943. Transactions of the Kansas Academy of Science 47: $61-88$.

Hoffman, J.D., J.R. Choate, and R. Channell. 2007. Effects of land use and soil texture on distributions of pocket gophers in Kansas. Southwestern Naturalist 52:296-301.

KennerLy, T.E. 1959. Contact between the ranges of two allopatric species of pocket gophers. Evolution 13: 247-263.

Kilmer, V.J., And L.T. Alexander. 1949. Methods of making mechanical analyses of soils. Soil Science 68:15-24.

KüChlER, A.W. 1974. A new vegetation map of Kansas. Ecology 55:586-604.

Lessa, E.P., AND C.S. Thaeler, JR. 1989. A reassessment of morphological specializations for digging in pocket gophers. Journal of Mammalogy 70:689-700.

LOVELl, D.C., W.R. Whitworth, J.R. ChOATE, S.J. Bissell, M.P. Moulton, And J.D. Hoffman. 2004. Geographic relationships of pocket gophers in southeastern Colorado. Transactions of the Nebraska Academy of Sciences 29:45-55.

Miller, R.S. 1964. Ecology and distribution of pocket gophers (Geomyidae) in Colorado. Ecology 45:256272.

Moulton, M.P., J.R. Choate, and S.J. Bissell. 1979. Sympatry of pocket gophers on Mesa de Maya, Colorado. Transactions of the Nebraska Academy of Science 82:194-195.

1983. Biogeographic relationships of pocket gophers in southeastern Colorado. Southwestern Naturalist 28:53-60.

RinkeR, G.C. 1941. Cratogeomys castanops from a recent terrace in southwestern Kansas. Journal of Mammalogy $22: 88$.

Rosenzweig, M.L. 1991. Habitat selection and population interactions: the search for mechanisms. American Midland Naturalist 137:S5-S28. 
Russell, R.J. 1968. Revision of pocket gophers of the genus Cratogeomys. University of Kansas Publications, Museum of Natural History 16:581-776.

Russell, R.J., AND R.H. BaKeR. 1955. Geographic variation in the pocket gopher, Cratogeomys castanops, in Coahuila, Mexico. University of Kansas Publications, Museum of Natural History 7:591-608.

SPSS, INC. 2002. 11.0.0 for windows [software]. SPSS Inc., Chicago, IL.
Vaughan, T.A. 1967. Two parapatric species of pocket gophers. Evolution 21:148-158.

ZAR, J.H. 1999. Biostatistical analysis. Prentice Hall, Upper Saddle River, NJ.

Received 5 December 2007 Accepted 20 May 2008 
APPENDIX 1. All known specimens of the yellow-faced and plains pocket gophers from west central Kansas, both museum specimens and specimens collected during the course of our study. Specimens are housed in the University of Kansas Natural History Museum (KU) and the Sternberg Museum of Natural History, Fort Hays State University (MHP). Localities are arranged alphabetically by county and reference locations, then by latitude (north to south) with respect to reference location and by longitude (west to east) at a particular latitude.

\section{Cratogeomys castanops}

Finney Co.: 19 mi S Dighton (38.2257 N, 100.4373 W), $4(\mathrm{KU}) ; 11.5 \mathrm{mi} \mathrm{N}, 3.5 \mathrm{mi}$ W Kalvesta $(38.23291 \mathrm{~N}$ $100.34070 \mathrm{~W}), 1$ (MHP); $10 \mathrm{mi} \mathrm{N}, 19.5 \mathrm{mi}$ W Kalvesta $(38.20521 \mathrm{~N}, 100.63346 \mathrm{~W}), 1(\mathrm{MHP}) ; 10 \mathrm{mi} \mathrm{N}, 3 \mathrm{mi} \mathrm{W}$ Kalvesta (38.21538 N, 100.33636 W), 1 (MHP); 9 mi N, $2.5 \mathrm{mi}$ W Kalvesta (38.1966 N, 100.3275 W), 2 (MHP); 8.5 mi N, $2.5 \mathrm{mi}$ W Kalvesta (38.1821 N, $100.3275 \mathrm{~W}), 1$ (MHP); 8 mi N, 2.5 mi W Kalvesta (38.1821 N, 100.3275 W), 2 (MHP); $6.5 \mathrm{mi} \mathrm{N}, 4.5 \mathrm{mi} \mathrm{W}$ Kalvesta $(38.1530 \mathrm{~N}$, $100.3641 \mathrm{~W}), 4$ (MHP); $5 \mathrm{mi} \mathrm{N}, 12.5 \mathrm{mi} \mathrm{W}$ Kalvesta $(38.13467 \mathrm{~N}, 100.50931 \mathrm{~W}), 1$ (MHP); $4 \mathrm{mi} \mathrm{N}, 12 \mathrm{mi} \mathrm{W}$ Kalvesta (38.1180 N, 100.5025 W), 2 (MHP); 3 mi N, 17.5 mi W Kalvesta (38.1052 N, $100.6088 \mathrm{~W}), 3$ (MHP); $5 \mathrm{mi}$ W Kalvesta (38.0658 N, $100.3824 \mathrm{~W}), 1$ (KU); $4 \mathrm{mi} \mathrm{W}$ Kalvesta (38.0658 N, 100.3641 W), 1 (KU); $3.4 \mathrm{mi} \mathrm{W}$ Kalvesta $(38.0658$ N, 100.3458 W), 1 (KU); 3 mi W Kalvesta (38.0658 N, 100.3458 W), 1 (KU). Ford Co.: $8.5 \mathrm{mi} \mathrm{N}, 6 \mathrm{mi}$ E Dodge City (37.8768 N, $99.9068 \mathrm{~W}), 6$ (KU); $7.5 \mathrm{mi} \mathrm{N}, 6$ mi E Dodge City (37.8623 N, 99.9068 W), 4 (KU); $6.5 \mathrm{mi}$ N, 4 mi E Dodge City (37.8477 N, 99.9433 W), 31 (KU); 5 mi N, 1 mi E Dodge City (37.8332 N, 99.9982 W), 2 (KU); $5 \mathrm{mi} \mathrm{N}, 2.5 \mathrm{mi}$ E Dodge City (37.8332 N, $99.9616 \mathrm{~W}), 4$ (KU); 2 mi N, $1 \mathrm{mi} \mathrm{W}$ Wright, Ford County Lake (37.8156 N, 99.9136 W), 4 (MHP). Gray Co.: $10 \mathrm{mi} \mathrm{N}, 4.5 \mathrm{mi} \mathrm{E}$ Cimarron (37.9640 N, 100.2543 W), 1 (KU). Hamilton Co.: $3.5 \mathrm{mi} \mathrm{N}, 0.15 \mathrm{mi}$ E Coolidge (38.0893 N, 101.9999 W), 1 (MHP); $3.2 \mathrm{mi} \mathrm{N}, 4.5 \mathrm{mi}$ E Coolidge (38.0772 N, 101.9270 W), 1 (MHP); Hamilton State Lake (38.0367 N, 101.8276 W), 3 (KU); $10.5 \mathrm{mi} \mathrm{N}, 6.5 \mathrm{mi} \mathrm{W}$ Syracuse $(38.1332 \mathrm{~N}$, $101.8719 \mathrm{~W}), 1$ (MHP); $6 \mathrm{mi} \mathrm{N}, 1 \mathrm{mi}$ E Syracuse (38.0637 $\mathrm{N}, 101.7250 \mathrm{~W}), 1$ (MHP); $5 \mathrm{mi} \mathrm{N}, 1 \mathrm{mi}$ W Syracuse $(38.0512 \mathrm{~N}, 101.7727 \mathrm{~W}), 1$ (MHP); $5 \mathrm{mi} \mathrm{N}$ Syracuse $(38.0658 \mathrm{~N}, 101.6630 \mathrm{~W}), 1(\mathrm{KU}) ; 4 \mathrm{mi} \mathrm{N}, 1.5 \mathrm{mi} \mathrm{W}$ Syracuse $(38.0367 \mathrm{~N}, 101.7910 \mathrm{~W}), 2(\mathrm{KU}) ; 4 \mathrm{mi} \mathrm{N}, 1 \mathrm{mi} \mathrm{W}$ Syracuse (38.0367 N, 101.7727 W), 5 (MHP); $3.5 \mathrm{mi} \mathrm{N}, 2$ mi W Syracuse (38.0391 N, 101.8170 W), 1 (MHP); $3 \mathrm{mi}$ N, 8 mi W Syracuse (38.0222 N, $101.9191 \mathrm{~W}), 2$ (MHP); 3 mi N, 1 mi E Syracuse (38.0243 N, 101.7249 W), 1 (MHP); $2.33 \mathrm{mi} \mathrm{N}, 0.5 \mathrm{mi}$ W Syracuse $(38.0076 \mathrm{~N}, 101.7544 \mathrm{~W}), 1$ (KU); $0.5 \mathrm{mi} \mathrm{N}, 0.5 \mathrm{mi}$ W Syracuse (37.9923 N, 101.7432 W), 2 (MHP); $0.5 \mathrm{mi}$ NW Syracuse (37.9931 N, 101.7544 W), 1 (MHP). Hodgeman Co.: $12.7 \mathrm{mi} \mathrm{W}$ Jetmore (38.0803 $\mathrm{N}, 100.1263 \mathrm{~W}), 1(\mathrm{KU}) ; 10.4 \mathrm{mi}$ W Jetmore $(38.0803 \mathrm{~N}$ $100.6897 \mathrm{~W}), 3$ (KU); 9 mi W Jetmore (38.0803 N, 100.0531 $\mathrm{W}), 2(\mathrm{KU}) ; 2.5 \mathrm{mi} \mathrm{S}, 3.5 \mathrm{mi} \mathrm{E}$ Jetmore $(38.0512 \mathrm{~N}$, $99.8336 \mathrm{~W}$ ), 8 (MHP); $2.75 \mathrm{mi} \mathrm{S}, 3 \mathrm{mi} \mathrm{E}$ Jetmore (38.0367 $\mathrm{N}, 99.8336 \mathrm{~W}), 2$ (MHP); $4 \mathrm{mi} \mathrm{S}, 0.5 \mathrm{mi} \mathrm{W}$ Jetmore, (38.0222 N, $99.9068 \mathrm{~W}), 1$ (KU); 9 mi S Jetmore (37.9495 N, $99.8885 \mathrm{~W}), 1(\mathrm{KU}) ; 10 \mathrm{mi} \mathrm{S}, 8 \mathrm{mi}$ W Jetmore $(37.9204$ $\mathrm{N}, 100.0531 \mathrm{~W}), 1$ (KU). Lane Co.: $14 \mathrm{mi} \mathrm{S}, 2.5 \mathrm{mi} \mathrm{E}$ Dighton (38.2697 N, 100.4191 W), 1 (MHP); $14 \mathrm{mi} \mathrm{S,} 6 \mathrm{mi}$ E Dighton $(38.2697 \mathrm{~N}, 100.3454 \mathrm{~W}), 1$ (KU); $15 \mathrm{mi} \mathrm{S}, 7.5$ mi E Dighton (38.2697 N, 100.3270 W), 1 (KU). Ness Co.: $2.5 \mathrm{mi} \mathrm{S}, 9 \mathrm{mi}$ W Ness City $(38.4145 \mathrm{~N}, 100.0694 \mathrm{~W}), 2$ (MHP); 3 mi S, 12 mi W Ness City (38.4145 N, 100.1246 W), 1 (MHP); 6 mi S, 12.5 mi W Ness City (38.3710 N, $100.1430 \mathrm{~W}), 1$ (MHP); $7 \mathrm{mi} \mathrm{S}, 13 \mathrm{mi}$ E Ness City (38.3566 N, 100.1430 W), 2 (MHP).

\section{Geomys bursarius}

Finney Co.: $0.5 \mathrm{mi} \mathrm{N}, 1.5 \mathrm{mi}$ E Friend $(38.26508 \mathrm{~N}$, $100.88715 \mathrm{~W}), 1$ (MHP); $5 \mathrm{mi} \mathrm{S}, 5 \mathrm{mi} \mathrm{E}$ Friend (38.19229 N, $100.81778 \mathrm{~W}$ ), 1 (MHP); $6.5 \mathrm{mi} \mathrm{S}, 2$ mi E Friend (38.16354 N, 100.86680 W), 1 (MHP); 9 mi N, 1 mi W Garden City $(38.10557 \mathrm{~N}, 100.88571 \mathrm{~W}), 1$ (MHP); $7 \mathrm{mi} \mathrm{N}, 1 \mathrm{mi} \mathrm{W}$ Garden City (38.07656 N, 100.88815 W), 1 (MHP); $3.7 \mathrm{mi}$ N, 0.5 mi W Garden City (38.0222 N, 100.8946 W), 1 (KU); $1.25 \mathrm{mi} \mathrm{N}, 0.5 \mathrm{mi}$ E Garden City (37.9931 N, $100.8763 \mathrm{~W})$, 2 (MHP); $1 \mathrm{mi} \mathrm{N}, 4 \mathrm{mi}$ E Garden City (37.98922 N, $100.80004 \mathrm{~W}), 1$ (MHP); 1 mi N, 4.5 mi E Garden City (37.98967 N, 100.79237 W), 1 (MHP); 1 mi S, $0.25 \mathrm{mi} \mathrm{W}$ Garden City (37.9349 N, 100.8946 W), 3 (MHP); 1 mi S Garden City (37.9495 N, 100.9861 W), 3 (KU); 1 mi S, 1.5 mi E Garden City (37.9495 N, 100.8398 W), 1 (MHP); 1 mi S, 1.5 mi E Garden City (37.9495 N, 100.8580 W), 1 (MHP); 2 mi S Garden City (37.9349 N, 100.9861 W), 2 (KU); 4.4 mi S Garden City (37.9059 N, $100.9861 \mathrm{~W}), 2$ (KU); 6.5 mi S Garden City (37.8768 N, $100.9861 \mathrm{~W}), 1$ (KU); $2.5 \mathrm{mi} \mathrm{S}, 0.5 \mathrm{mi}$ E Holcomb (37.9495 N, $100.9861 \mathrm{~W})$, 2 (MHP); 2.5 mi S, 1 mi E Holcomb (37.9495 N, 100.9678 W), 3 (MHP); $3.5 \mathrm{mi} \mathrm{S}, 1.75 \mathrm{mi}$ E Holcomb (37.9349 N, $100.9678 \mathrm{~W}$ ), 1 (MHP); $7.5 \mathrm{mi} \mathrm{S}, 1 \mathrm{mi} \mathrm{W}$ Holcomb (37.9059 $\mathrm{N}, 101.0593 \mathrm{~W}), 2$ (MHP); $11.5 \mathrm{mi} \mathrm{S}, 3 \mathrm{mi} \mathrm{W}$ Holcomb $(37.8156 \mathrm{~N}, 101.0435 \mathrm{~W}), 9$ (MHP); $11.5 \mathrm{mi} \mathrm{S}, 3.5 \mathrm{mi} \mathrm{W}$ Holcomb (37.8156 N, 101.0617 W), 22 (MHP); $12 \mathrm{mi} \mathrm{S}$, $3.75 \mathrm{mi}$ W Holcomb (37.8011 N, 101.0617 W), 9 (MHP); 1 mi S Pierceville (37.8623 N, 100.6751 W), $3(\mathrm{KU}) ; 8.1 \mathrm{mi} \mathrm{S}$ Pierceville (37.7576 N, 100.6790 W), 1 (KU). Ford Co.: 1 mi N, 2 mi E Bloom (37.4965 N, 99.8590 W), 2 (MHP); 1 mi N, $2.5 \mathrm{mi}$ E Bloom (37.5110 N, $99.8407 \mathrm{~W}), 1$ (MHP); $0.5 \mathrm{mi} \mathrm{N}, 2.5 \mathrm{mi} \mathrm{E}$ Bucklin $(37.5691 \mathrm{~N}, 99.5856 \mathrm{~W}), 2$ (MHP); 24 mi E Dodge City (37.7496 N, $99.5782 \mathrm{~W}), 1$ (MHP); 1.3 mi S Dodge City (37.7286 N, 100.0230 W), 2 (KU); 3 mi SW Dodge City (37.7141 N, 100.0776 W), 18 (KU); 2 mi S, 23 mi E Dodge City (37.7039 N, 99.6110 W), 1 (MHP); 3.8 mi SW Dodge City (37.7141 N, 100.0959 W), 5 (MHP); $3.5 \mathrm{mi} \mathrm{S}, 23 \mathrm{mi}$ E Dodge City (37.7054 N, 99.7395 W), 1 (MHP); $4.5 \mathrm{mi} \mathrm{N}, 0.5 \mathrm{mi}$ E Ford (37.6620 N, 99.7488 W), 1 (MHP); $4.5 \mathrm{mi} \mathrm{N}, 7.5 \mathrm{mi} \mathrm{E}$ Ford (37.6998 N, 99.5957 W), 1 (MHP); $1.5 \mathrm{mi} \mathrm{N}, 2.5 \mathrm{mi} \mathrm{W}$ Ford (37.6706 N, $99.8043 \mathrm{~W}), 1$ (MHP); $1.5 \mathrm{mi}$ N Ford (37.6669 N, 99.8026 W), 1 (MHP); 3 mi S Howell (37.7431 N, 100.1688 W), 1 (MHP); $10 \mathrm{mi} \mathrm{N}, 4.5 \mathrm{mi} \mathrm{W}$ Mullinville $(37.7431 \mathrm{~N}$, 99.5674 W), 2 (MHP). Gray Co.: 3 mi E Cimarron (37.8011 $\mathrm{N}, 100.2963 \mathrm{~W}), 1(\mathrm{KU}) ; 1 \mathrm{mi} \mathrm{S}$ Cimarron (37.7866 N, $100.3510 \mathrm{~W}), 1$ (KU); $1.6 \mathrm{mi} \mathrm{S}$ Cimarron $(37.7866 \mathrm{~N}$, $100.3510 \mathrm{~W}), 1$ (KU); 2 mi S Cimarron $(37.7721 \mathrm{~N}, 100.3510$ W), 2 (KU); 2.5 mi S Cimarron (37.7721 N, $100.3510 \mathrm{~W}), 2$ (KU); 3.7 mi S, $5.5 \mathrm{mi}$ E Cimarron (37.7517 N, 100.2497 W), 1 (MHP); 4.5 mi S Cimarron (37.7431 N, 100.3510 W), 1 (KU); $5.3 \mathrm{mi}$ S Cimarron (37.7286 N, $100.3510 \mathrm{~W}), 1$ (KU); 5.8 mi S Cimarron (37.7286 N, $100.3510 \mathrm{~W}), 1(\mathrm{KU}) ; 6$ mi S Cimarron (37.7141 N, 100.3510 W), $2(\mathrm{KU}) ; 6.4 \mathrm{mi} \mathrm{S}$ Cimarron (37.7141 N, $100.3510 \mathrm{~W}), 1$ (KU); $7.2 \mathrm{mi} \mathrm{S}$ Cimarron (37.6996 N, 100.3510 W), 1 (KU); $7.6 \mathrm{mi} \mathrm{S}$ Cimarron (37.6996 N, 100.3510 W), 2 (KU); $7.7 \mathrm{mi} \mathrm{S}, 8.5$ mi W Cimarron (37.6931 N, 100.5083 W), 1 (MHP); 3.2 mi S, 2 mi W Ingails (37.7733 N, $100.4932 \mathrm{~W}), 1$ (MHP). Hamilton Co.: 1 mi E Coolidge (38.0076 N, 101.7544 W), 
APPENDIX 1. Continued.

Geomys bursarius (continued)

1 (MHP); 1.5 mi S, 2 mi E Coolidge (38.0132 N, 101.9707 W), 1 (MHP); 2 mi S, $4.5 \mathrm{mi} \mathrm{E}$ Coolidge $(38.0010 \mathrm{~N}$ $101.9227 \mathrm{~W}), 1$ (MHP); $6 \mathrm{mi} \mathrm{W}$ Kendall (37.9364 N, $101.6685 \mathrm{~W}), 1$ (MHP); $0.5 \mathrm{mi} \mathrm{S}, 4 \mathrm{mi} W$ Kendall (37.9290 $\mathrm{N}, 101.6153 \mathrm{~W}$ ), 1 (MHP); $2.5 \mathrm{mi} \mathrm{N}, 0.5 \mathrm{mi} W$ Syracuse $(38.0076 \mathrm{~N}, 101.7544 \mathrm{~W}), 2(\mathrm{KU}) ; 2.3 \mathrm{mi} \mathrm{N}, 0.5 \mathrm{mi} \mathrm{W}$ Syracuse (38.0076 N, $101.7544 \mathrm{~W}), 2(\mathrm{KU}) ; 2.2 \mathrm{mi} \mathrm{N}, 0.5$ mi W Syracuse (38.0076 N, 101.7544 W), 2 (KU); 2 mi N, $0.5 \mathrm{mi} \mathrm{W}$ Syracuse $(38.0076 \mathrm{~N}, 101.7544 \mathrm{~W}), 2(\mathrm{KU}) ; 1.5$ mi N, $0.5 \mathrm{mi} \mathrm{W}$ Syracuse (38.0076 N, $101.7544 \mathrm{~W}), 2$ (KU); $0.75 \mathrm{mi} \mathrm{N}, 0.5 \mathrm{mi}$ W Syracuse $(37.9931 \mathrm{~N}, 101.7544 \mathrm{~W}), 1$ (KU); $0.5 \mathrm{mi} \mathrm{N}, 6 \mathrm{mi} \mathrm{W}$ Syracuse $(37.9907 \mathrm{~N}, 101.8710$ W), 1 (MHP); $0.5 \mathrm{mi} \mathrm{N}, 3.2 \mathrm{mi} W$ Syracuse (37.9752 N, $101.8269 \mathrm{~W}), 1$ (MHP); $3.7 \mathrm{mi}$ S Syracuse $(37.9349 \mathrm{~N}$, $101.7544 \mathrm{~W}), 1(\mathrm{KU}) ; 4.5 \mathrm{mi} \mathrm{S}$ Syracuse $(37.9204 \mathrm{~N}$, $101.7544 \mathrm{~W}), 1$ (KU); $5.3 \mathrm{mi} \mathrm{S}$ Syracuse $(37.9059 \mathrm{~N}$, 101.7544 W), 1 (KU). Kearny Co.: $0.25 \mathrm{mi} \mathrm{N}, 3 \mathrm{mi} \mathrm{W}$ Deerfield (37.9786 N, 101.1873 W), 4 (MHP); $0.75 \mathrm{mi} \mathrm{S}$, $0.25 \mathrm{mi}$ E Deerfield (37.9689 N, 101.1216 W), 1 (MHP); $10 \mathrm{mi} \mathrm{N}$ Lakin $(38.0803 \mathrm{~N}, 101.2605 \mathrm{~W}), 2(\mathrm{KU}) ; 3.5 \mathrm{mi} \mathrm{N}$, $4 \mathrm{mi}$ E Lakin (37.9331 N, 101.1873 W), 1 (KU); $5.5 \mathrm{mi} \mathrm{W}$ Lakin (37.9349 N, 101.3520 W), 2 (KU); $2.25 \mathrm{mi}$ W Lakin (37.9349 N, 101.2971 W), 2 (KU); 1.8 mi E Lakin (37.9349
$\mathrm{N}, 101.2239 \mathrm{~W}), 2(\mathrm{KU}) ; 2.5 \mathrm{mi} \mathrm{E}$ Lakin $(37.9349 \mathrm{~N}$, 101.2056 W), 1 (KU); 2.7 mi E Lakin (37.9349 N, 101.2056 W), 1 (KU); 2.8 mi E Lakin (37.9349 N, 101.2056 W), 1 (KU); 4 mi S Lakin (37.8768 N, 101.2605 W), 1 (KU); 8 mi S Lakin (37.8156 N, 101.2621 W), 2 (KU); 14.9 mi S, 4.5 mi E Leoti $(38.2548 \mathrm{~N}, 101.2422 \mathrm{~W}), 1$ (KU); $15.2 \mathrm{mi} \mathrm{S}$, 4.5 mi E Leoti (38.2548 N, 101.2422 W), 1 (KU). Lane Co.: $3.5 \mathrm{mi} \mathrm{N}$ Alamota (38.5158 N, 100.3086 W), 4 (MHP); 3.5 mi N, 0.25 E Alamota (38.5158 N, 100.3086 W), 4 (MHP); $3.5 \mathrm{mi} \mathrm{N}, 1 \mathrm{mi}$ E Alamota $(38.5158 \mathrm{~N}, 100.2902 \mathrm{~W}), 3$ (MHP); $3.25 \mathrm{mi} \mathrm{N}, 1 \mathrm{mi}$ E Alamota (38.5013 N, 100.2902 W), 1 (MHP); 2 mi E Dighton (38.4869 N, 100.4375 W), 1 (KU); 1 mi S Dighton (38.4724 N, 100.4559 W), 1 (KU); $4.7 \mathrm{mi} \mathrm{S}$ Dighton (38.4145 N, $100.4559 \mathrm{~W}), 2$ (KU); $8.5 \mathrm{mi}$ S, 6 mi E Dighton (38.3566 N, 100.3638 W), 1 (MHP); 9 mi S, 6 mi E Dighton (38.3566 N, 100.3638 W), 1 (MHP); Pendennis (38.6316 N, 100.3270 W), 4 (KU). Ness Co.: 2.5 mi N, $2.5 \mathrm{mi}$ E Brownell (38.6765 N, 99.6963 W), 1 (MHP); $5.3 \mathrm{mi} \mathrm{N}, 2 \mathrm{mi} \mathrm{W}$ Ness City (38.5371 N, 99.9388 W), 1 (MHP), $5.1 \mathrm{mi} \mathrm{N}, 2 \mathrm{mi} W$ Ness City $(38.5338 \mathrm{~N}$, 99.9416 W), 2 (MHP); 5 mi N, 2 mi W Ness City (38.5310 N, 99.9371 W), 1 (MHP); 1 mi S, 16 mi W Ness City (38.4434 N, 100.1982 W), 1 (KU).

APPENDIX 2. All plains pocket gophers used for this study from outside the study area. Localities are based on museum records and illustrated in Fig. 2. Specimens are housed in the University of Kansas Natural History Museum (KU) and the Sternberg Museum of Natural History, Fort Hays State University (MHP). Localities are arranged alphabetically by county and reference locations, then by latitude (north to south) with respect to reference location and by longitude (west to east) at a particular latitude.

Edwards Co.: 1 mi N Kinsley (37.9349 N, 99.4128 W), 1 (KU); 1.5 mi S Kinsley (37.9059 N, 99.4128 W), 3 (KU); 10 mi N, $4.5 \mathrm{mi} \mathrm{W}$ Mullinville (37.7431 N, 99.4763 W), 2 (KU). Grant Co.: 4 mi N, 5 mi E Ulysses (37.6271 N, $101.2804 \mathrm{~W}), 1(\mathrm{KU}) ; 2.5 \mathrm{mi} \mathrm{S}, 1 \mathrm{mi}$ W Ulysses $(37.5400 \mathrm{~N}$, $101.3715 \mathrm{~W}), 1$ (KU); $11 \mathrm{mi} \mathrm{S}, 4.5 \mathrm{mi}$ W Ulysses (37.4240 N, 101.2257 W), 1 (KU). Greeley Co.: 4.75 mi E Tribune (38.4724 N, 101.6705 W), 1 (KU). Haskell Co.: 4 mi S, 4 mi W Satanta $(37.3950 \mathrm{~N}, 101.0617 \mathrm{~W}), 2(\mathrm{KU})$. Kiowa Co.: 1.75 mi E Belvidere (37.4530 N, 99.0572 W), 1 (KU); $1.5 \mathrm{mi} \mathrm{S}, 3.5 \mathrm{mi}$ E Belvidere $(37.4530 \mathrm{~N}, 99.0207 \mathrm{~W}), 5$ (KU); 6 mi N Greensburg (37.6996 N, 99.2941 W), 4 (KU); $3 \mathrm{mi} \mathrm{N}, 2$ mi E Greensburg (37.6561 N, 99.2576 W), 7 (KU); Greensburg (37.6126 N, 99.2941 W), 1 (KU); 6 mi S, $2 \mathrm{mi} \mathrm{W}$ Greensburg (37.5255 N, 99.3305 W), 1 (KU); $6 \mathrm{mi}$ $\mathrm{N}$ Haviland (37.7141 N, $99.1118 \mathrm{~W}), 1$ (KU); $5.5 \mathrm{mi} \mathrm{N}$ Haviland (37.6996 N, 99.1118 W), 1 (KU); 2 mi N Haviland (37.6416 N, $99.1118 \mathrm{~W}), 1$ (KU); Haviland (37.6271 N, 99.1118 W), 1 (KU); $4 \mathrm{mi} \mathrm{N}, 0.75$ mi E Wellsford (37.6126 N, 99.0389 W), 1 (KU). Pawnee Co.: 2 mi N, 5 mi E Larned (38.2112 N, 99.0104 W), $5(\mathrm{KU}) ; 1 \mathrm{mi} \mathrm{N}, 6 \mathrm{mi} \mathrm{E}$ Larned (38.1966 N, $98.9921 \mathrm{~W}), 2$ (KU); $0.5 \mathrm{mi} \mathrm{S}, 2.5 \mathrm{mi}$ W Larned (38.1676 N, 99.1384 W), 3 (KU); 1 mi S, $0.5 \mathrm{mi}$
E Larned $(38.1676 \mathrm{~N}, 99.0835 \mathrm{~W}), 1(\mathrm{KU}) ; 1.25 \mathrm{mi} \mathrm{S}$ Larned (38.1676 N, 99.1018 W), 3 (KU); 2 mi S, $1 \mathrm{mi} \mathrm{W}$ Larned (38.1530 N, $99.1201 \mathrm{~W}), 1$ (KU); $2.5 \mathrm{mi} \mathrm{S}, 1 \mathrm{mi} \mathrm{W}$ Larned (38.1385 N, 99.1201 W), 1 (KU). Scott Co.: Lake Scott State Park (38.3131 N, $100.7503 \mathrm{~W}), 1$ (KU); $9.5 \mathrm{mi}$ $\mathrm{N}, 0.5 \mathrm{mi}$ E Manning (38.6869 N, $100.7135 \mathrm{~W}), 1$ (KU); $7.5 \mathrm{mi} \mathrm{N}, 1.5 \mathrm{mi} W$ Manning (38.6606 N, $100.7503 \mathrm{~W}), 1$ (KU); $12 \mathrm{mi} \mathrm{N}, 4 \mathrm{mi} \mathrm{W}$ Scott City (38.6461 N, $99.8670 \mathrm{~W})$, 1 (KU); 4 mi S Scott City (38.4289 N, 100.8975 W), 2 (KU). Stanton Co.: 3 mi W Johnson City (37.5691 N, 101.8088 W), 1 (KU); 2 mi N of Manter (37.5546 N, 101.8817 W), 2 (KU); $1 \mathrm{mi} \mathrm{N}, 6 \mathrm{mi} \mathrm{W}$ Manter $(37.5400 \mathrm{~N}, 101.9911 \mathrm{~W}), 2$ (KU); $3 \mathrm{mi} \mathrm{N}, 1.5 \mathrm{mi} W$ Saunders (37.5110 N, 102.0093 W), 1 (KU); $2 \mathrm{mi} \mathrm{N}, 3.75 \mathrm{mi} \mathrm{W}$ Saunders (37.4965 N, 101.9911 W), 1 (KU). Trego Co.: $10 \mathrm{mi} \mathrm{S}, 16 \mathrm{mi} \mathrm{E}$ Trego Center (38.73940 N, 99.59777 W), 1 (MHP); 10.5 mi S, 16 mi E Trego Center (38.73579 N, 99.59949 W), 1 (MHP); $11 \mathrm{mi} \mathrm{S}, 16 \mathrm{mi}$ E Trego Center (38.73181 N, $99.59941 \mathrm{~W}$ ), 1 (MHP). Wichita Co.: 11.9 mi S Leoti (38.3131 N, 101.3376 W), 1 (KU); $10 \mathrm{mi} \mathrm{N}$ Marienthal (38.6316 N, 101.2104 W), 1 (KU); 17 mi W Scott City (38.4869 N, 101.2288 W), 3 (KU); 15 mi W Scott City (38.4869 N, 101.1920 W), 3 (KU). 